Western University Scholarship@Western

1970

\title{
Recent Canadian Monetary Policy: An Appraisal
}

Thomas J. Courchene

Follow this and additional works at: https://ir.lib.uwo.ca/economicsresrpt

Part of the Economics Commons

Citation of this paper:

Courchene, Thomas J.. "Recent Canadian Monetary Policy: An Appraisal." Department of Economics Research Reports, 7016. London, ON: Department of Economics, University of Western Ontario (1970). 
Research Report 7016

RECENT CANADIAN MONETARY POI.ICY:

AN APPRAISAL

Thomas J. Courchene ${ }^{*}$

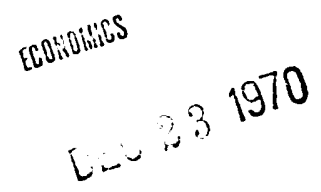

\footnotetext{
* I wish to thank Grant Reuber both for his comments on an earlier draft and for his role in kindling mv interest in current policy issues. In addition, ticipants of the Queen's many valuahle comments $J$ received from the paradian Experience". views expressed must rest with of this sort, however, responsihility for the research underlying the paper.
}

Tune, 1970 


\section{CANADIAN MOINETARY POLICY: AN APPRAISAL}

Not since the late fifties and the reign of "Coynesian" economics has there been as much concern over Canadian monetary policy as there is at the present time. In part this concern stems from the central bank's current anti-inflationary policies in the face of mounting unemployment, culminating finally with the floating of the dollar. But it also reflects a more basic questioning of the operations of the Bank of Canada over the recent past. The purpose of this paper is to review the highlights of Bank polfcy since 1965 and to assess the appropriateness of this policy. This assessment, which proceeds on a year-to-year basis, addresses the suitability of Canadian policy both from the vantage point that Canada is able independently to chart her own policy course and then within the more realistic context of a small open economy linked to the world via a fixed exchange rate. In order to address these issues, however, it is necessary to turn briefly to some institutional factors characterizing the $1965-1970$ period.

\section{Institutional Background}

The 1967 Bank Act legislation is "by far the most momentous revision of the Bank Act" [14, p. 28] and the dominant factor altering the institutional setting of the Canadian monetary system over the 1965-1969 period. From a uniform rate of $8 \%$ on all Canadian dollar deposits, the legal minimum reserve ratio was changed to $12 \%$ on demand deposits and to $4 \%$ on deposits requiring notice. Under the old Bank Act, the $3 \%$ reserve ratio could be (but never was) altered. However, the new dual rate is immutable. The secondary reserve ratio (ratio of Treasury bills, day-to-day loans, ard cash in excess of the primary reserve ratio to Canadian dollar deposit liabilities) instituted via mora] 
suasion in 1956, is now incorporated into the bank legislation. Set initially at $6 \%$, It can be altered between zero and $12 \%$. This switch from variability in the primary reserve ratio to variability in the secondary reserve ratio is, in my opinion, quite acceptable from the Bank's point of view since the bank calibrates monetary policy largely in terms of credit conditions rather than some monetary aggregate. Given this approach, the Bank should prefer to have a variable liquid-asset ratio since this gives it more direct control where it deems the action to be--on the asset side of the chartered-banks' balance sheet. The second major provision of the bank legislation was to remove the $6 \%$ Interest ceiling on chartered-bank loans. In theory, this has an effect very mucl: like the lifting of the Regulation "Q" would have in the U.S. Coupled with the lowered reserve requirements on notice deposits, this provided both the ability and tine incentive for chartered banks to promote term deposits relative to demand deposits. Not surprisingly, Table $I$ indicates that this is precisely what happened. Fixed-term personal savings deposits grew at an average annual rate of $114 \%$ over the two year period from mid-1.967 to mid-1969 and non-chequable savings deposits at $78 \%$ per year. Chequable savings deposits declined by nearly $13 \%$ yearly. Indeed the sum of demand deposits plus chequable personal savings deposits declined over this two-year period at an annual rate of $41 / 2 \%$. Other term and notice deposits (which are similar to $\mathrm{CD}^{\prime}$ 's in the U.S.) exhibit an annual growth rate of only $10.8 \%$ compared to the much larger growth rates of other fixed-term deposits. This, however, is due largely to an agreement in October 1967 among the major banks (at the implicit request of the Governor) to limit the extent to which they nould attempt to attract these deposits. ${ }^{1}$ Table I

1 increase the degree of competition in the frinciplas underlying the Bank Act was to after the provisions after the provisions began to be implemented, the removal of the ceiling rate on
the asset side was replaced with a Regulation " $Q$ " type restriction on the 1iability
side in orcie: to curb the power of the banking side in orcie: to curb the powar of the banking sector reiative to the near-banks. 


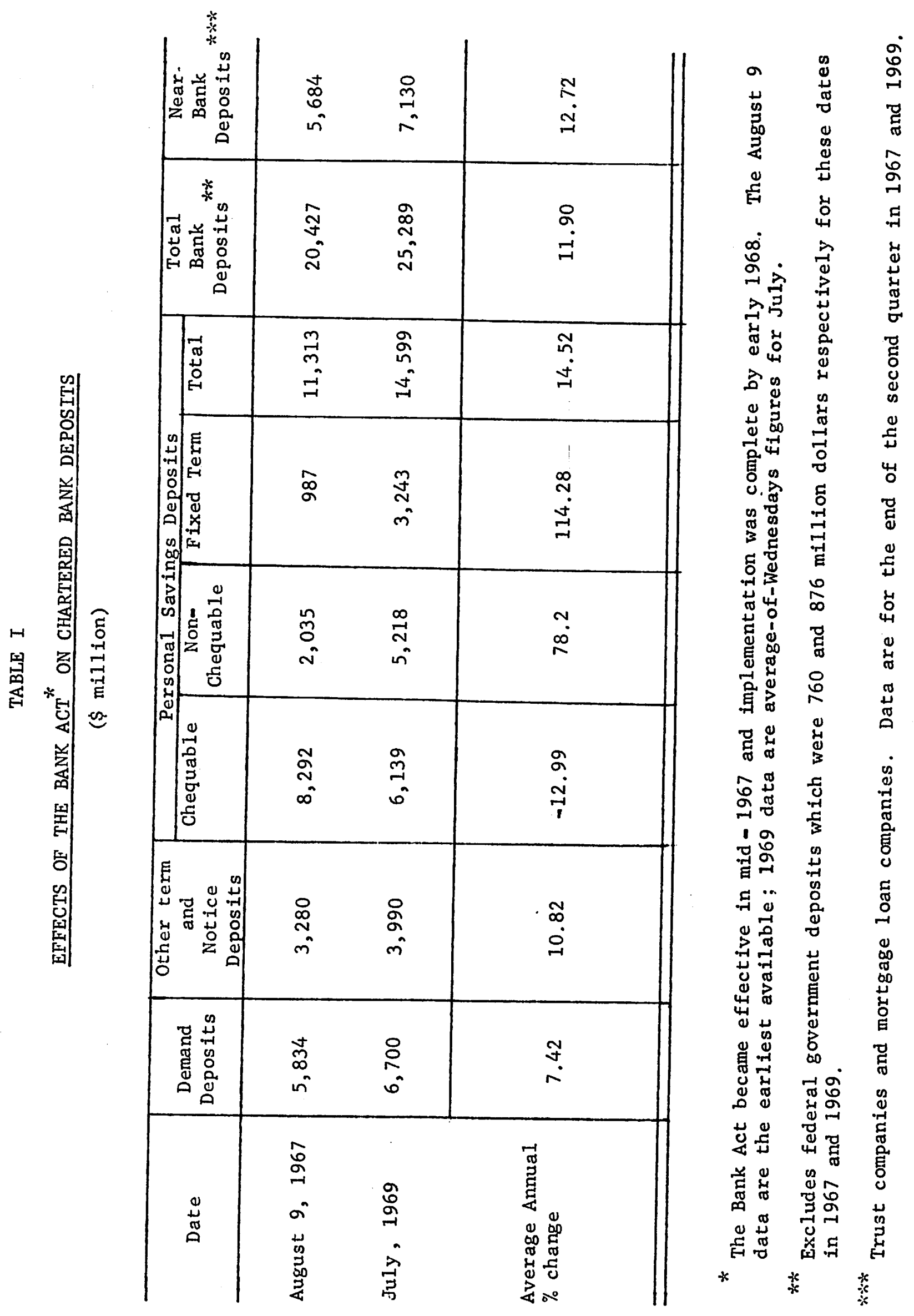


also indicates that for the two-year period the rate of growth of bank deposits was not at the expense of near-bank growth: trust and mortgage loan companies experienced growth rates averaging above $12 \%$ over this period compared with a 9.4\% increase in the year prior to the adoption of the Bank Act.

Clearly then, the Bank Act represents a major structural change in the Canadian banking and financial milieu--a change of such magnitude that it seriously complicates the analysis of monetary policy. Take the definition of money, for example. The generally accepted definition in the recent past included all Canadian dollar deposits of the chartered banks. It is not at all clear that this definition is still appropriate. In addition, depending on the particular aggregate selected, the annual rate of growth in the chartered-bank component of the money supply for these two years can be well into the teens or it can be negative. As a result, several definitions will be considered, although primary emphasis is still given to formulations embodying total Canadian dollar liabilities.

In addition to Canadian dollar deposit liabilities, the chartered banks also accept foreign currency liabilities. At the end of 1969 these liabilities held by Canadian residents were in excess of three billion dollars--amounting to nearly $13 \%$ of the total of publicly held Canadian dollar deposit liabilities. About half of these deposits were in the form of "swapped deposits". 2 No reserves are required on these foreign currency deposits. Further on the international side, accompanying Canada's fixed exchange rate was a ceiling on the level of international reserves she could hold. This ceiling, set at or near 2.6 billion (U.S. \$), was the price Canada paid for being exempted from the Interest Equalization Tax (IET) provisions. In December 1968 the ceiling was

2 Funds converted into a foreign currency, usually U.S. dollars, which have been placed on term deposit with a bank and which the bank has undertaken through a forward contract to convert back into Canadian dollars at maturity. 
removed but in return Canada agreed to invest all reserves in excess of wori:ing balances in non-liquid U.S. government bonds. Finally, on May 31, 1970 the Canadian dollar was set free. As we shall see, these facets of Canada's international position affected the conduct of Canadian monetary policy over the 1965-69 period. The remainder of the institutional factors are best introduced 1ater.

II. Canadian Nonetary Policy, 1965-1970

Table II, containing quarterly data from 1965 to 1969 on various monetary and financial series, provides the statistical backdrop for most of the analysis of recent Canadian monetary policy. Several monetary aggregates appear: total publicly-held Canadian dollar deposit liabilities (column 1), total (including government) Canadian dollar liabilities (column 2), ${ }^{3}$ and currency plus demand deposits, (column 3). U.S. counterparts to two of these series are in columns 4 and 5. Regardless of which series one focuses upon, one fact is very clear; both the rate of growth and the variability in the rate of growth of money are considerably greater in Canada than in the U.S. For fublicly-held bank money the quarter-to-quarter growth rate (at annual rates) is $23.2 \%$ in 1968 . II and the first difference in the rate of growth reaches an astounding $22.4 \%$ from 1969.1 to 1969. II.

Monetary Indicators and Bank Policy

It is obvious from these figures that the Bank of Canada in conducting its monetary policy is not following a money supply rule. Indeed the Governor is quite explicit on this point:

${ }^{3}$ These first two series exclude currency since the Bank of Canada maintains that in its operations it does not allow a currency drain to affect the level. of reserves which it deems to be appropriate. For an empirical verification of this see Courchene [7]. 
"The Bank regards its chief function in the field of monetary policy as being to help bring about the kind of credit conditions that are appropriate to domestic economic conditions and to the maintenance of the country's external financial position. By credit conditions I mean the cost and availability of money throughout the economy. .... In the day-to-day determination of monetary policy, the central bank is not primarily influenced by consideration relating to the size of the money supply. This does not mean of course that the Bank of Canada takes no interest in, or is not influenced by, what is happening to the money supply (which in Canada is usually defined as the combined total of currency outside banks and chartered bank deposits payable in Canadian dollars.) However, it is a fact that we do not operate on the basis of a precise view about the appropriate trend, over some period, of total chartered bank deposits. We give priority in our thinking to the kind of credit conditions that seem to be appropriate in the prevalling circumstances." $[15, \mathrm{Pp} .10,11$, 12]

"...the concept of the money supply... is one which I, myself, do not regard as the essential operational concept in the conduct of monetary policy." [11, p. 1034].

Canadian monetary policy is, therefore, calibrated with reference to conditions relating to nominal rates of interest and the availability of credit. That nominal rates can be a misleading indicator of monetary policy especially under conditions of inflationary expectations is well documented, 4,5 and in the analysis that follows it will become clear that calibrating monetary policy with reference to nominal interest rates was one of the major errors of Bank pólicy over this period.

${ }^{4}$ See, for example, the paper by Fand [9] and references therein.

5 While I side with the monetarists on this issue I do feel that they have not adequately shored up their own position on the rate of growth of the money supply as the appropriate monetary indicator. From a theoretical standpoint it should not much matter which of the various monetary aggregates one chooses as the monetary indicator provided that the demand equation for this variable incorporates the effects of the whole spectrum of near monies. But this sort of approach is not generally followed so that in periods where the structure of the financial system is changing (in Canada because of the Bank Act, or in the U.S.A. because of the effect of Regulation "م") the various candidates for the money supply can lead to divergent views on the stance of monetary policy. 
Acheson and Chant in a recent paper [1] take this further. They suggest that over the years the Bank's focus on credit conditions in combination with its desire to minimize debt managemert costs has reduced the Canadian shortterm money market to the position where the chartered banks and the Bank of Canada are the only effective participants. There is clear evidence even over the past five years of this trend towards the elimination of the general public from the government securities markets. At the end of 1964 the Bank of Canada held $23.2 \%$ of the outstanding Treasury bills and the chartered banks and the general public held $60.8 \%$ and $16.9 \%$ respectively. For December, 1969 these percentages were $16.9 \%, 73.8 \%$ and $9.3 \%$ respectively. ${ }^{6}$ The same trend shows up for marketable government bonds as well. In 1964 the public accounted for $52.5 \%$ of government bonds and the chartered banks held $25.8 \%$, the Rank holding the remaining $21.7 \%$. In 1969 these ratios were $43.1,31.4$ and 25.4 . Quantitatively, the increase in all marketable bonds and b111s from 1964 to 1969 was $\$ 2,626$ mi1lion. Chartered bank holdings increased by $\$ 2,239$ million, and central bank holdings by $\$ 1,001$ million while holdings by the public declined by $\$ 614$ million. The net result of the Bank's interest rate policy was that the entire government deficit over this period had to be financed via the banking system and the some! 7

Given, then, that the Bank interprets its role as influencing the cost and avallability of credit, it is natural to expect that focus be directed more

6Acheson and Chant [1] interpret this development as resulting from the Bank's exercising its power of moral suasion which included, in 1956, the implementation of a secondary reserve ratio. In 1955 the general public accounted for the largest proportion of Treasury hills. Indeed, their dollar volume of bill holdings were considerably larger in 1955 than in 1969.

${ }^{7}$ And these deficits (cash requirements) were large; $\$ 85$ million in 1965-66; $\$ 872$ million in 1966-67; $\$ 911$ million in 1967-68; $\$ 1,103$ million in 1968-69; $\$ 5$ million in 1969-70. (Source: Budget Papers, nttawa, Queen's Printer; 1970, Part II. 
toward the asset rather than the liability side of the chartered-banks' balance sheet and in particular to the loan behaviour of the banks. Unfortunately, the Bank appears to chart the course of chartered-bank loan behaviour in a very indirect manner. Under the lagged reserve-settlement system, reserves held at the central bank during the current month are determined by the level of deposits in the preceding month. The evidence avallable seems to suggest that the Bank of Canada validates the chartered-bank decisions regarding the level of deposit liabilities: central bank advances to chartered banks and investment dealers are small, infrequent and of ten not indicative of tightness when they do occur, indicating that there are sufficient reserves for the banking system but that on occasion a particular bank finds itself in trouble and is forced directly, or through the investment dealers, into the Bank. This being the case, the Bank has to find some way to influence the level of deposit Iiabilities the chartered banks are willing to create or, alternatively, the level of loans that the banks are willing to extend. They attempt to do this hy affecting bank liquidity and more specifically the more-liquid-asset (MLA) ratio (defined beneath Table II). Therefore, if the Bank of Canada wishes to pursue a restrictive policy it engages in operations that attempt to make.it in the chartered banks own interest to pursue restraint.

It is important to recognize that this approach toward reserve managment is not independent of the Bank's concern with credit conditions and minimizing the servicing cost of government debt: a more aggregressive reserve policy would require sharp movements in interest rates which the Bank is not willing to tolerate, and cost minimization of the federal debt implies on occasion sharp upward movements in the MLA ratio. It is our contention that these factors, in combination with the monetary discipline imposed on Canada by the fixed exchange rate, account in large measure for both the size and variability of monetary growth over the 1.9651969 period. 
With these concepts in mind we now turn to a more detailed analysis of Canadian monetary policy.

1965

From the record:

"in the early years of the economic expansion, so long as there was a considerable amount of slack in the economy, the policy of to be met without was to allow the increasing demands for credit the rising output of the growing productive capacity in hegan to catch up with its and credit conditions were in $1965 .$. this policy was modified,

But from the rate of expansion of the privately-held bank money (12 $1 / 2 \%$ in 1965) policy was anything but tight. This is especially so in comparison with 1964 when the rate of increase in bank money was about one-half the 1965 increase. In part, what the Governor means is that interest rates (col. 11, Tahle II) rose somewhat in 1965 even though the "Bank of Canada resisted the downward pressure on bond prices by purchasing Government securities in the market after February 10 " and "limited to about 10 basis points" [2, p. 25] the rise in Canadian ratesand in the process allowed the money supply to increase in the first quarter by over $15 \%$ at annual rates.

But there is another sense in which central bank might consider bank conditions as tightening--the MLA ratio was falling. (It averaged about 33\% in 1964.) Indeed, generating a fall in this ratio was one of the principal goals of policy:

"Beginning in April the cash management of the Bank of Canada was conducted in such a way that the continued strong expansion of the chartered banks' loans brought about a further reduction in the ratio of their "more liquid" assets to total assets."

Given that the Bank wished to pursue monetary restraint, a more aggressive policy toward restricting reserves would have brought about an even greater decrease in this ratio and with a substantially smaller increase in loans.

Why was the banking system expanding so rapidly when the announced policy of the authorities was one of restraint? Discarding the possibility that the Bank of Canada wanted this expansion, two alternatives suggest themselves. First, 
the combination of a fixed exchange rate and a reserve ceiling that was effective (see Table II) seriously constrained Canadian monetary policy. A smaller degree of monetary expansion would have, in the short run, widened the Canadian-U.S. interest-rate differential and led to foreign exchange inflows above the ceiling level. My own personal view is that this juxtaposition of fixed rate and fixed celling did indeed reduce the flexibility of Canadian monetary policy and policy in 1965 reflected this limitation.

However, the Governor does not feel that the ceiling poses any special restriction on the flexibility of Canadian monetary policy:

"On your more basic question... as to whether the combination of the fixed exchange rate and our understandings with the United States regarding the level of reserves narrows the scope for monetary policy in Canada, I think my quick reaction to that is to say that there is still enough scope to worry about... I I think that it is the case that whatever exchange system we have in Canada, in a country where international transactions are as important as they are here, that we are bound to be influenced in the conduct of our affairs, including the conduct of monetary policy, by what is going on in other parts of the world and particularly in the United States." [11, p. 1066].

Later in his remarks, Governor Rasminsky stated that the reserve ceiling could be evaded by the Canadian government repurchasing its own securities in the American market and in this way use up an excess foreign exchange. 8 But in light of the concern that arose in 1.968 in connection with the flexibility of Canadian monetary policy and the reserve celling and the pleasure expressed by the Governor upon its removal I find it difficult to visualize how Canada could have followed a policy of effective monetary constraint in 1965 without violating the ceiling requirement.

A second possibility (and one mentioned in the previous section) for the large expansion in 1965 is that the Bank's interpretation of the lagged reservesettlement scheme allows the chartered banking system to play the dominant role

${ }^{8}$ It is appropriate to point out that the Governor is referring to the situation in 1966 rather than 1965 in these remarks. As Reuber [17] indicates the Government did repatriate $\$ 140$ million of its own securities in early 1966 as a means of evading the reserve ceiling. 
in setting the level of bank liabilities. If th be the case that the Rank of Canada merely accedes, in providing reserves in the current month, to the rate of expansion set by the chartered banks in the previous month--and the evidence on borrowings mentioned above suggests that this may well be the case--then the Bank of Canada is bound to experience difficulties in regulating monetary expansion. The fact that the Bank focuses on the more-liquid-asset ratio is evidence that there is considerable truth to the suggestion that in the short run chartered-bank behaviour governs the rate of expansion of total bank money. In the longer run the Bank of. Canada influences monetary expansion not so much by influencing reserves firectly but rather by forcing the banks into positions where it is in their own interest to restrict loan and deposit expansion. This can lead to substantial slippage in the implementing of policy:

"In 1964 the Bank of Canada managed the cash reserves of the chartered hanks in such a way that a part of the resources needed by the hanks to accommodate the large increase in their loans had to be obtained through a reduction in their holdings of government securities and other liquid assets. This reduction in bank liquidity was not such as to prevent the banks from continuing to follow strong lending policies but it brougtt them to a position where their policies could be expected to be sensitive to any appreciable further decline in the proportion of their total assets which they held in relatively liquid form." [11, p. 1014, underlining is not in the original.]

But it took until the fourth quarter of 1965 and the first quarter of 1966 for bank money and loans respectively to reflect this "tightening." Indeed, both loans and money grew at higher rates in 1965 than in 1964. In order to prevent the tail from wagging the dog it would appear highly desirable for the Bank to announce ahead of time what level of reserves it will. make avaflable in the following month and to allow the chartered banks to react accordingly. Such a procedure would shorten considerably the reaction of time of the chartered banks to official policy, and would also serve to clarify for all sectors of the economy just what official policy is. But in order for the Bank to even consider such a policy it must be more wllling than it has heen in the past to tolerate interest rate changes. A policy of maintaining interest rates at a given level implies that 


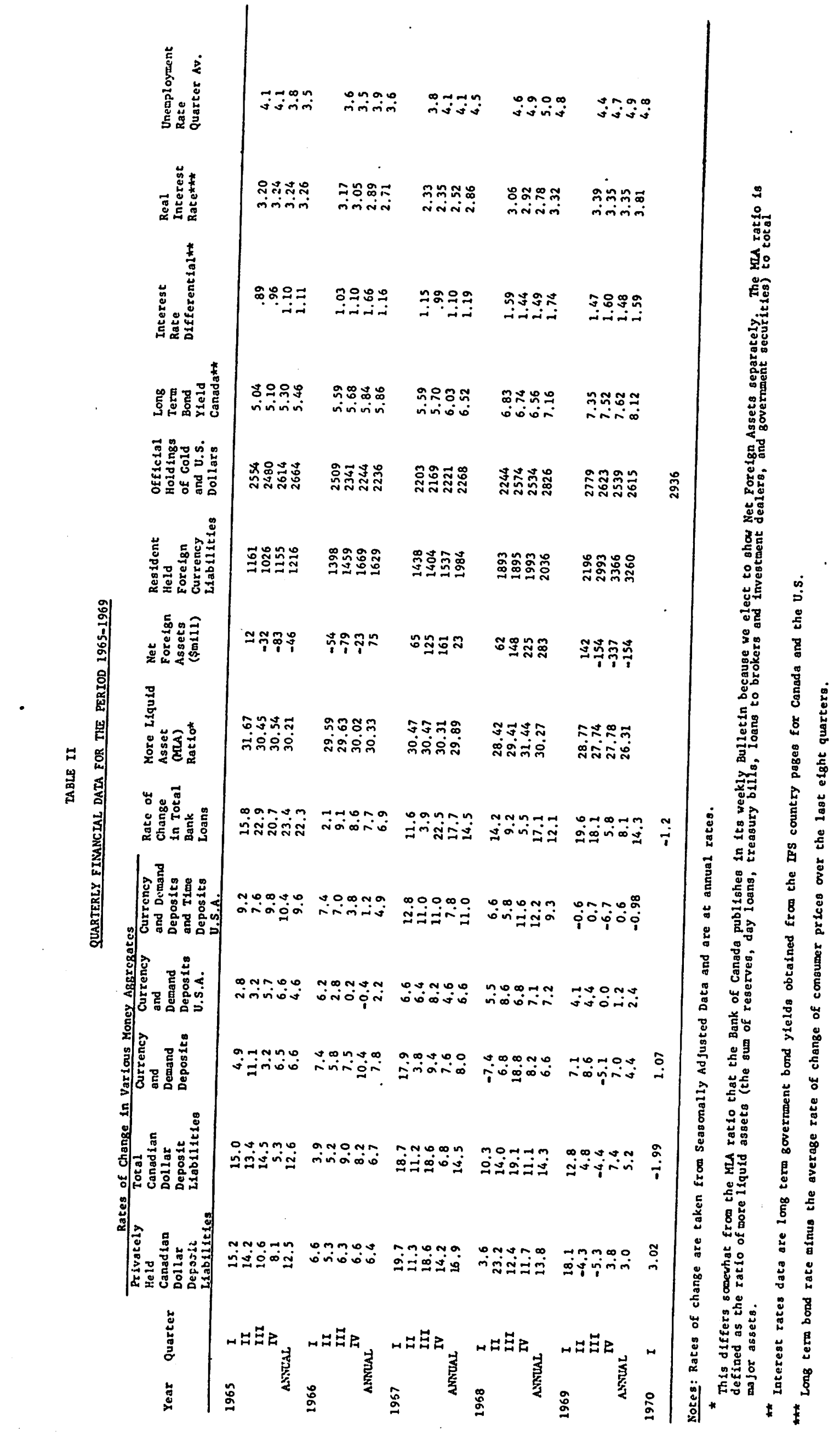


the supply of money will be demand determined.

Before one Eaults the Bank for inadequate implementations of its announced policy in 1965, however, there is one extenuating circumstance that must be considered. In June 1965 the Atlantic Acceptance Corporation (a medium-sized sales-finance company) failed and many of its subsidiaries went under as well. This was a severe shock to the financial sector and the Bank reacted immediately, and successfully, to avoid a major financial panic. Part of the large rates of increase in the monetary aggregate for the second and third quarters of 1965 is undoubtedly a reflection of what the Bank considered as appropriate monetary conditions in the presence of the financial crisis: "Where ... confidence is in danger of being seriously impaired the central bank may have to allow itself to be diverted from the pursuit of current objectives of monetary policy and give priority to measures which help to maintain confidence." [2, p. 7] 1966
"In the latter part of 1965 and the early part of 1966 demand pressures on the economy became particularly intense and credit conditions progressively tightened. The Bank Rate was raised in December 1965 and again in March 1966 when I stated that the 'Bank's action reflected its view that in the present state of the economy some moderation of the rate of growth of over-all demand was desirable." $[3$, p. 5].

This view underlines the concern about inflationary dangers expressed in the 1965 Annual Report of the Bank released on the same day the Bank Rate was raised (March 11, 1966). Later in the year the Bank "considered that the appropriate policy was for it to offer considerable resistance to further tightening of credit conditions without, however, attempting to prevent a11 further upward movement in interest rates. This course involved some relaxation of the short rein it had kept on the banking system." [3, p. 5]. Note, however, that the Bank is identifying rising nominal interest rates with 
tightening credit conditions. While it is true that nominal rates were rising, real interest rates declined continuously throughout 1966 (Table II) so the true cost of credit fell in 1966. But the availability of credit (as measured by the rate of expansion of bank money or loans) was considerably tighter than in 1965 or 1967. Nonetheless, in absolute terms the rate of monetary expansion is still considerable--well above the real growth rate of the economy. At this juncture we might note that from 1965 through 1967 the rates of expansion of Canadian money we re greater than those in the U.S. (under any definition, but Table II presents comparable figures only for currency plus demand deposits). Under a monetary interpretation of the balance of payments, this should lead to reserve outflows and is one of the underlying causes of the foreign exchange crisis in early $1968 .^{9}$

$\underline{1967}$

"Credit conditions became very tight in 1966 [but not relative to those in the U.S.A., T.J.C.], and with the evidence of a slackening in the pace of economic activity I welcomed the opportunity to help bring some easing of credit conditions." $[4$, p. 8$]$.

Accordingly, the Bank Rate was reduced twice in the first four months of 1967. But in the spring of 1967 it became obvious that the economy was strong and expanding :
"The basic problem for monetary policy in 1967 was to decide how far to permit the very large demands for funds in capital and credit markets...to exert pressures on interest rates and how far to accommodate the demand by permitting increased monetary expansion. In the event, we experienced a mixture of the two--rising interest rates and considerable monetary expansion--until the closing months of the year when there was a marked slowing down in the rate of monetary growth." [4, p. 9].

9 For an empirical analysis of the relationship between domestic monetary expansion and foreign exchange flows for most of the industrial countries see Courchene [8]. 
Essentially, then, the central bank was "leaning against the wind" in attempting to resist: interest rate increases: "the alternative was to permit the market pressures to exert an even stronger and earlier impact on interest rates." [4, p. 10]. But while nominal interest rates were about $6 \%$ in the last half of 1967, real rates were less than $3 \%$. Furthermore, the longer run impact of this high rate of monetary expansion was to increase and not decrease nominal interest rates. In addition, the monetary expansion was quite inconsistent with the Governor's continuing deep concern in the 1967 Annual Report with inflationary pressures. And it is even more inconsistent with his statement: "I continue to hope that exclusive reliance will not be placed on monetary and fiscal policy to achieve this result [i.e., better price and wage performance, T.J.C.]". [4, pp. 7-8 $]^{10}$

The Bank Act revision which began to take effect in mid-1967 probably complicated Bank of Canada operations. Released from special restrictions, the chartered-banking system began attracting term deposits away from near banks. A more restrictive policy towards bank reserves would have seriously affected near-bank growth. As it was, the near banks found themselves in enough trouble:

\footnotetext{
"The banks naturally took advantage of these changes to compete more aggressively for an enlarged share of the total financial business of the community. Indeed, for a period in the autumn their competition for large blocks of short-term corporate funds was so aggressive that it appeared to be uneconomic, and I felt that it threatened to introduce some instability and distortion into the financial system. I informed the banks of my vicw and was gratified that a more normal relationship of rates came about soon after." [4, p. 9].
}

10

It is interesting to note that in nearly every Annual Report the Governor calls for some sort of commission to influence wage and price behaviour, e.g. "I hope that the public authorities will take the lead in seeking to influence the various groups in the econony who wield power to relate their demands for: increases in money incomes more realistically to increase in their real output than has been the case in the past couple of years." [4, p. 8]. In simpler terms, Canada's Prices and Incomes Commission is the brain-child of the Bank of Canada. 
This gratification took the form of persuading the five large banks to agree among themselves to limit the degree to which they would compete for these funds. In other words, they imposed upon themselves a voluntary Regulation "Q"type restriction. One result of this was that the banks encouraged their customers to switch to foreign currency deposits where this restriction was not binding. As Table II indicates, these foreign currency deposits increased by approximately $\$ 450$ million in the fourth quarter of 1967 . The Covernor's statement above that the rate of growth of monetary expansion slowed markedly in the closing months of 1967 is not true if one includes in the definition of money resident holdings of foreign as well as domestic currency liabilities of the banking system--a definition that has considerable merit in a world-economy context.

1968

"For the first half of 1968 the Bank gave top priority to
the defence of the exchange value of the Canadian dollar.
Bank Rates reached a peak of $7 \frac{1}{2} \%$ in mid-March and was main-
tained at that level to the beginning of July. Market rates
rose to the highest levels that we had ever experienced in
this country up to that time. Bank liquidity declined and
the rate of expansion of the banking system slowed markedly."
[5, p. 8].

This last statement relating to monetary expansion is not supported by evidence in Table IJ. Privately held bank money rose in the second quarter at an annual rate of $23 \%$ ! Including government deposits, the rates of increase of the banking system were $10 \%$ and $14 \%$ respectively for the first two quarters. Again the Bank is focusing on the movements in interest rates and the MLA ratio in judging the stance of monetary policy.

Once the exchange rate crisis was over the Bank "moved to make monetary policy less restrictive and reduced the Bank Rate [in the third quarter] in 
three steps from $71 / 2 \%$ to $6 \% "[5$, p. 8$]$. The result was a record $19.1 \%$ increase in total chartered bank 1fabilities and a further $12 \%$ increase in total private bank money following on the heels of the $23 \%$ increase in the second quarter.

These rates of increase in bank money in 1967 and 1968 are absurdly high and surely represent the low point of recent Bank of Canada monetary policy. ${ }^{11}$ In part, the mid-1968 increases reflect the Bank's belief that the U.S. surcharge would have a damping effect on both economies. But in large measure the Bank was again "leaning against the wind". In the Governor's words, "we had to take into account...the practical limitations on increases in interest rates that exist at any given time." [5, p. 9]. The federal government required cash and to obtain it via bond financing to the public would have pushed rates up too high. And, the Bank argued, if rates were allowed to go that high capital would have flowed in and the government would have needed even more cash in order to buy the resulting inflows of foreign exchange (this problem arose again in 1970 and eventually led to the abandonment of the fixed exchange rate). As a result the Bank of Canada permitted the charteredbanking sustem to purchase large quantities of federal government bonds. In turn, this increased the chartered banks' MLA ratio by over $3 \%$ from $1968 . T$ to 1963.JII--hy rar the largest increase over the 1965-1970 neriod. Given that the Bank flaces so much emphasis on this ratio (and that for the first time in well over a year loan expansion was less than $10 \%$ for two successive quarters, 1968. II and 1968.T.II) it is extremely hard to rationalize this increase in bank liquidity. But certainly it makes very evident the high priority the Bank assigns to interest-cost minimization and underscores the problem associated

11 The Governor, too, was embarrasser hy these hish rates of expansion and tool partial refuge in arguing strongly for a narrover definttion of money, i.e., currency plus demand deposits, (5, pp. 9-10) which exhibits a much sma:ller increase over 1968 . 
with calibrating monetary policy in terms of nominal interest rates. The Bank also recognized that these liquid assets were getting out of hand and "accordingly managed cash reserves in such a way that the chartered banks" holdings of such assets ceased to rise after mid-September, and the rate of expansion of the banking system was slowed." [5, p. 9]. But the damage was done and was reflected in the high rates of loan expansion over the next three quarters, counteracting the Bank's attempt to pursue tight money!

The combination of the fixed exchange rate and the reserve ceiling also appears to have been a major factor in Bank policy in $1968 .^{12}$ During the exchange-rate crisis early in the year, the Canadian-U.S. interest-rate differential was increased substantially (Table II) and the resulting inflows of foreign exchange again threatened to push Canada's reserves through the $\$ 2.6$ billion ceiling, thereby once again converting the Bank of Canada into the position of being the (unlucky) thirteenth Federal Reserve District. Appropriately enough, "increasing concern was expressed in Canada that the flexibility of Canadian monetary policy was in danger of being severely limited by a target level for Canadian exchange reserves" [5, p. 14] and in December, after an exchange of letters between Canada and the U.S., the reserve ceiling was removed. The interest differential between Canada and the U.S. for the fourth quarter of 1968 reflects this extra degree of freedom: it is considerably larger than any previous differential and had the effect of increasing Canada's reserves well beyond the previous ceiling level.

$\underline{1969}$

"Since the autumn of 1968, when it became clear that the anticipated moderation of inflationary pressures was not occurring, monetary policy has

12 It is appropriate to point out that regional economic disparities within Canada probaìly also serve to constrain Bank policy. Corresponding to the overall Canadian unemployment rate of $4.5 \%$ in 1968 . IV were the following regional unemployment rates: British Columbia 5.1\%; Prairie provinces $2.7 \%$; Ontario $3.2 \%$; Quebec $7.2 \%$; Atlantic provinces $7.3 \%$. Any tightening of Bank policy would merely add to the already serious unemployment problems in the provinces east of Ontario. 
again been directed toward restraint" [6, pp. 10-11]. The Bank Rate, increased in December, was raised again in February. But a first quarter increase of $12.8 \%$ in total bank money and $18.1 \%$ in privately-held bank money hardly reflects restraint! Again the Central Bank is probably referring to the upward movements in interest rates and the falling MLA ratio. And again the Bank of Canada is allowing the chartered banks to determine the rate of growth of banking system. In the first weeks of the second quarter the more-' liquid-asset ratio fell to a "new low up to that time", but the chartered banks appeared willing to run this ratio down even lower. The Bark resorted to more drastic action. In April the secondary reserve ratio was increased from $7 \%$ to $8 \%$, thus impounding about $\$ 250$ million of the banks' 1iquid assets. In addition the Central Bank requested that the banks 1imit the rates they would pay on short-term Canadian-dollar certificates of deposit. As a result privately-held bank money declined at an annual rate of over $4 \%$. But the chartered banks were not to be outdone: faced with the prospect of losing term deposits to near banks they began attracting foreign currency deposits to reinvest in the lucrative Euro-dollar market. Resident holdings of these deposits increased by $\$ 800$ million in the second quarter of 1969 (Table II). 13 Redefining bank money as deposits of Canadian residents in Canadian or foreign currency results in an increase in privately held bank money of nearly $8 \%$ from 1969.I to $1969 . I I$.

In the first two weeks of the third quarter foreign currency deposits shot up by a further $\$ 350$ million. In addition chartered-bank loans increased by $18.1 \%$ in the second quarter, financed in part by drawing down net foreign

13

Foreign currency liabilities held by both residents and non-residents increased by nearly 2 billion dollars in the first half of 1969. 
assets by $\$ 300$ million (Table II), and were still increasing rapidly. The Bank

responded by placing a dollar limit on these foreign currency "swapped deposits and increasing further the Bank Rate. Even though the banks drew down their net foreign assets by a further $\$ 233$ million the restraint was now on in full force. Loan expansion was way down in the third quarter and all monetary aggregates registered substantial declines. Real interest rates were now well above $3 \%$ and at their highest rates for the 1965-1969 period.

1970

With unemployment remaining near $5 \%$ monetary restraint continued, the chartered banks finally being forced to decrease loans outstanding in the first quarter of 1970 by $1.2 \%$ on an annual basis. Once again, however, Canadian monetary policy ran headlong into the realities of the fixedexchange-rate system. Monetary restraint resulted in substantial foreign exchange inflows--over $\$ 300$ million in 1970.1 (Table II). In order to sterilize these inflows the Bank had to draw down government balances at the chartered banks. This is reflected in the difference in the growth rates of the monetary aggregates--private bank money increased at an annual rate of $3.02 \%$ while total bank money declined by $1.99 \%$. But sterilization simply kept Canadian interest rates higher than they would otherwise have been and the reserve flows began flowing in all the faster. On March 30 , the Governor removed the ceiling on foreign currency "swapped deposits" hoping that they would increase and relieve the pressure on the Canadian dollar. This proved to be ineffective against the swelling inflow. From 
the end of March to the first week in May, government deposits at the chartered banks fell from slightly over $\$ 1$ billion to $\$ 233$ million most of this decrease going to insure that the continuing foreign exchange inflow did not increase bank reserves. In order to maintain sufficient government balances to enable future sterilization the Government announced a special bond issue of $\$ 250$. To insure that the banks bought this issue the Governor raised the secondary reserve ratio from $8 \%$ to $9 \%$--enough to immobilize more than the whole of the new bond issue. When the reserve inflow continued unabated, the Bank began operating in the forward market. But this, too, offered no relief. Faced with the alternative of having to follow an expansionist monetary policy in order to maintain the par value of the Canadian dollar, the government announced (on Sunday, May 31) that the Exchange Fund would no longer maintain the value of the Canadian dollar within the IMF limits: Canada was back on a flexible rate.

III. Résumé

From an analýtical vantage point, one can indict Canadian monetary policy over this period on three counts: i) selection of inappropriate monetary indicators, $i i)$ an inefficient procedure to effect desired monetary policy, and iii) a less-than-full appreciation of the dictates underlying the Fixed-rate system. We shall treat these in turn. Rates of monetary expansion well into the teens are simply not tolerable. Even policy reversals (i.e., changes in the rate of change) were above $10 \%$ on many occasions, i.e., an increase in the rate of change of privately held bank money of over $17 \%$ from 1968.I to 1968.II followed by an $11 \%$ fall in the rate of change to 1968.III. In large measure these policies were a result of focusing on nominal rates of 
interest in particular and credit conditions in general as the indicator of monetary policy. "Leaning against the wind" in 1967 and 1968 served not to decrease but rather to increase interest rates and to worsen the inflation. Even the Governor now recognizes this:

"...it would be a mistake to over-estimate the capacity of a central bank, by following an easy monetary policy in inflationary conditions, to bring about lower levels of interest rates that would last for any significant period of time. No doubt the central bank could, by undertaking a rapid monetary expansion, cause some temporary reduction in short-term interest rates but this would increase inflationary expectations and indeed bring about a situation that was in fact more inflationary, so that the longer-term result would almost certainly be a higher rather than a lower level of interest rates." [17, p. 13.]

Recognition of this in 1965 rather than 1969 would have led to far more stability in the rates of monetary expansion and far more appropriate monetary policy! Less important, perhaps, is the inefficient manner in which the Bank carries out its desired policy. On several occasions (e.g., 1965.I, 1969.IV) the lag between the announced policy and the reflection of this policy in the balance sheets of chartered banks is somewhere in the neighborhood of six to nine months. This unacceptably long lag arises because the Bank focuses on the MIA ratio as the means of influencing chartered bank lending activities. This is a result of the Bank's reserve-creation policy which automatically validates last month's deposit liabilities which in turn results from the Bank's sensitivity to interest rate changes. The consequence of this is that for long periods of time the commercial banks are able to chart their oun course of monetary expansion. ${ }^{14}$ In addition, the MLA ratio leaves much to be desired as an indicator. For one thing the debt management policies followed

${ }^{14}$ Indeed, given the existence of large unutilized portions of business loan authorizations and the availability of automatic personal overdrafts under schemes like "chargex" one could argue that it is the public and not the chartered banks who control monetary expansion. I would argue, however, that if the chartered banks feit that reserves would not be forthcoming automatically to val:date their increase in liabilities they would take a more restrictive approach toward these overdraft privileges. 
during this period resulted in large upward movements in this ratio, often at times when the announced policy was one of restraint. Furthermore, it probably shares many of the defects of the "free reserves" concept. Given the current levels of interest rates and income, and the expectations regarding their future movements there exists, for the banks, a desired MLA ratio. A different set of conditions will generate a different desired MLA ratio. Therefore a given value for the MLA ratio can be consistent with varying degrees of bank restraint. Essentially precisely this problem occurred in 1969 when the chartered banks kept on expanding assets and liabilities even though their MLA ratio was at its historic low. ${ }^{15}$ A far better procedure would be for the Bank of Canada to announce publicly what rate of growth of reserves it deems appropriate in the following month or months, supplemented perhaps by movements in the secondary reserve ratio to exert greater influence on the lending policies of the banks. In addition to shortening the "inside" lag of monetary policy this procedure would also clarify for the general public the current stance of monetary policy. 16

\section{Monetary policy under a fixed-rate regime}

Under a fixed-exchange rate the monetary policies of the smaller countries must be geared largely to balance-of-payments considerations. Given the level of incone, population growth, etc., in Canada and the stance of monetary policy

${ }^{15}$ Nute that in 1969 the banks' more liquid assets embodied more "liquidity".the ratio of bills to bonds was much greater than in the earlier periods.

${ }^{16}$ In this connection, I am sympathetic to some of the criticism levelled at the Bank of: Canada in a recent paper by Acheson and Chant [1] especially with regard to the air of secrecy surrounding, and the degree of personalization (i.e., amphasis on moral suasion) governing, Bank policy. 
in the world economy, there exists a given level of monetary expansion that is consistent with a given level of international reserves. Fluctuations in reserve levels permit some flexibility in individual countries' monetary policies. But with the advent of the massive Euromdollar market it is becoming increasingly difficult for countries to pursue independent monetary policies. The behaviour of resident-held foreign currency deposits exemplifies this well: the large increases in these deposits occurred in 1966, 1967.IV, 1969.II and 1969. IV--all periods when the Bank of Canada was actively pursuing restrictive policy! At the height of the restraint (1969.III) the Bank was forced to put a dollar ceiling on these deposits. It is interesting to note that if one defines bank money to include resident holdings of both foreign as well as Canadian dollar liabilities of the chartered banks this series exhibits considerably less variability than that of privately held bank money.

But fixing the quantity as well as the price of U.S. dollars effectively emasculates monetary policy. And such was Canada's predicament during most of the 1965-70 period. ${ }^{17}$ Viewed in this 1ight Canada's policy with respect to monetary expansion is in part understandable. But in this broader context the Bank must bear some responsibility for Canada's adherence to the exchange rate

${ }^{17}$ Tro combon fallacies need clarification at this juncture. First, it is often claimcd that since the behaviour of the Canadian money supply differs from the U.S. counterpart, the Canadian position is not equivalent to being the thirteenth Federal Reserve district. But endogeneity does not require identical growth rates. If the behaviour of money in the Ist Federal Reserve district differs frar that in the 12th Federal Reserve district, is the money supply in the 12th district exogenous? Second, a constant rate of growth of money is preferable to a widely variable growth rate. This is probably true for a country with a flexible exchange rate or for a country like the U.S.A. (with a very sinall foreign sector relative to the GNP) under fixed rates. But the fixedexchange-rate system inposes a given path of monetary expansion for countries like Canada and it is far from clear that a fixed rule would be consistent with this required growth rate. However, given the erratic behaviour of the Canadian money supply, it appears that from 1965-70 an expansion-to-rule policy would have been superior. The fact that the noney aggregate including foreign currency deposits exhibits more stability than the Canadian dollar series suggests that Bank pulicy need not have been so variable. 
and subsequent subjection to the wage and price spirals plaguing the interpational economy. And in the end we were forced to abandon the fixed exchange rate system anyway. The appropriate time to appreciate the exchange rate (or set it free) was in 1965 or perhaps 1967 and not in 1970. With the international economy strong and inflationary expectations in their infancy in 1965 Canada, under a policy of appreciating or freeing the dollar, could have pursued a monetary policy slightly less restrictive than that of the U.S. and obtained an enviable trade-off between inflation and unemployment. As it turned out, however, the movement to a floating rate and appreciation was adopted as an emergency measure and in a time of slackening world economic activity so that in the short run at least the effect will be to gain a onceand-for-all reduction in price levels at the expense of an increase in the already high rate of unemployment.

Furthermore, it is not at all clear that Canada will enjoy any of the benefits that a flexible exchange rate can bestow. In order to insure that the rate would not appreciate too much the Bank of Canada announced (also on May 31,1570 ) a reduction in the Bank Rate, thereby easing credit conditions in Canada. In addition, the Minister of Finance suggested that the kxchange Fund would be active in maintaining the dollar at the "appropriate" level. If monetary policy is utilized to achieve and maintain a particular value for the dollar then, in effect, Canada has an appreciated and not a floating exchange rate. $^{18}$ But, in theory at least, Canada now has obtained flexibility in the conduct of her monetary policy.

On these three issues, then, the Bank's performance is clearly substandiard. However, to assert that monetary policy was inappropriate throughout

18 The authorities would be well advised to study Mundell's assessment [12] of Canacia's experience under the 1950-1962 floating rate in order to avoid
past mistakes. 
this period may be going too far. Monetary policy is part of overall public policy and in the last analysis should be viewed in this context since the Governor is responsible to the Minister of Finance. Both fiscal policy (especially in 1967 and 1968) and the concern over regional disparity probably forced the Bank to be more expansionist than it otherwise would have been. And the acceptance of the reserve ceiling in return for exemption under the IET provisions was a further constraint that overall policy imposed on the conduct of monetary policy. In addition, the Bank successfully carried the Canadian economy through two crises (the domestic financial crisis in the summer of 1965 and the January 1968 exchange-rate crisis) and to stave off a third the Bank (and Government) resorted to a flexible exchange rate. Considering that Canada is one of the most open economies in the world and the international moneta:y system went through its most trying period since Bretton Woods, the Bank must be given some credit for keeping the country on a relatively even keel throughout 1965-1970. All things considered, however, we still contend that Canacian monetary policy over the past five years leaves much to be desired. As a final comment we direct attention to the role of the Prices and Incomes Commission (PIC). In that the Bank proposed, helped staff, and is one of the most ardent suppoiters of the PIC it seems appropriate to include the operations of the PIC as reflecting, at least peripherally, the viewpoint of the Bank of Canada. One of the factors contributing to the formation of the PIC was the belief that "present policy tools are not sufficient to resolve the very real conflict that exists at the present time betwcen the objectives of maintaining high level employment and restoring the price stability than is necessary for sustained economic growth" [10, p. 10] and that "despite large government borrowing requirements and other factors, monetary policy has played a major role in restraining growth of demand. Interest rates hive risen to very high levels" [10, p. 22]. But we have just demonstrated 
that monetary policy contributed to, rather than restrained, demand growth. It is unfortunate that the prevailing view in official ottawa circles is that conventional macro policy tools have done all they could to fight inflation, but their best was not enough. 19

The Commission's role is to "discover the facts, analyze the causes, processes and consequences of inflation and to inform both public and government of: how price stability may be achieved" [10, p. 28]. In its work, the PIC has been embarking on a program of voluntary wage and price controls (see Reuber [19]). As a short run measure this may or may not be fruitful--the benefits of any shift in the Phillips curve toward a better price-unemployment trade-off must be set against the cost of potential resource misallocation. As a long run approach to the inflation problem under a fixed-rate regime, however, j.t is questionable, to say the least. Canada will continue to inflate at or near the rate of inflation in the world (U.S.A.) economy. Now that tine exchange rate is freed the PIC has, in theory, a greater role to play--for good or bad. 20

On the role of monetary policy over the 1965-1969 period and also indirectly on the role of the Prices and Incomes Commission, the last word belongs to R.A. Mundel1 [13, p. 64.1, fn. 6].
"When, as in 1950, Canada was faced with a situation in which the U.S. economy was involved in the Korean war and threatened by inflation, while Canada had, only a year before devalued, the choice was inflation or a change in the exchange rate, and the Canadian authorities wisely chose to let the Canadian dollar appreciate rather than be forced into going along with the U.S. inflation. In ... [12] ... ar argued that a situation analogous to 1950 had appeared and that Canada should again let her exchange rate float upward according to free market forces. But that time the Bank opted for inflation instead."

\section{Reuber [19] scores the authorities on this point.}

20 It is important to note, however, that the PIC in its public statements never viewed the fixed-exchange rate system as an obstacle in its flight against
inflation. 


\section{Literature Cited}

1. Acheson, Keith and John Chant, "The Bank of Canada: A Study in Bureaucracy," Paper read to the annual meetings of the Canadian Economics Association, Winnipeg, June 1970.

2. Bank of Canada, Annua1 Report, 1965.

3. _.. Annual Report, 1966.

4.

5. — Annua1 Report, 1968.

$6 . \ldots$ Annual Report, 1969. and A. K. KeIly,

7. Courchene, Thomas J./ "Money Supply and Money Demand: An Econometri.c Analysis for Canada," Research Report No. 7009, University of Western Ontaric, London, Canada, 1970 (forthcoming in the Journal of Money Credit and Banking).

8. Courchene, Thomas J., "The Price-Specie. Flow Mechanism and the Gold Exçnange Standard: Some Exploratory Empiricism Relating to the Endogeneity of Country Money Balances," Research Report No. 7010, University of Western Ontario, London, Canada, 1970.

9. Fand, David I., "Some Issues in Monetary Economics," Federal Reserve Bank of St. Louis Review (January 1970), pp. 10-27.

10. Government of Canada, Policies for Price Stability, (Ottawa: Queen's Printer, 1968).

11. House of Cotmonon, Standing Committee on Finance, Trade and Economic Affairs, Minutes of Procendings and Fvidence No. 19, 27th Parlianent,
Ist Sess. 1966 .

12. Munde11, Robert A., "Problems of Monetary and Exchange Rate Management in Canada," National Banking Review (September, 1.964), pp. 77.86.

13. ___ "Toward a Better International Monetary System," Journal of Money Credit and Banking, (August 1969), pp. 625-648.

14. Perry, J. Harvey, "1967 Bank Act Revision," The Canadian Banker, Sumner 1967, pp. $28-43$.

15. Rasminsky, Iouis, "Central Banking in the Canadian Financial System," Opening address by the Governor of the Bank of Canada to the 20th International banking Summer School, Queen's University, Kingston, Ontario, August 15, 1967.

16. "Defending Against Inflation," Address by the Govcrnor of the Bank of Canada to the Canadian Club of Winnipeg, (Nov. 1, 1967). 
17. Rasminsky, Louis, "Interest Rates and Inflation," Statement by the Governor before the House of Commons Standing Comittee on Finance, Trade and Economic Affairs, July 3, 1969.

18. Reuber, Grant L., "Recent Monetary Policy in Canada - I," Bankers Magazine, (February, 1967), pp. 73-78.

19. "Incomes Policy: Canada's Experiment with Organized Voluntarism to Curb Price Inflation," Research Report 7003, Univirsity of Western Ontario, London, Canada, 1970. 